\title{
THE EFFECT OF N-STEAROYLETHANOLAMINE ON THE LIPID COMPOSITION OF THE RAT TESTES AND TESTOSTERONE LEVEL DURING THE EARLY STAGES OF STREPTOZOTOCIN-INDUCED DIABETES
}

\author{
O. V. ONOPCHENKO ${ }^{凶}$, T. M. HORID'KO, H. V. KOSIAKOVA, \\ A. G. BERDYSHEV, V. M. KLIMASHEVSKY, N. M. HULA \\ Palladin Institute of Biochemistry, National Academy of Sciences of Ukraine, Kyiv; \\ ৫e-mail: onop.89.av@gmail.com
}

Received: 23 December 2019; Accepted: 27 March 2020

\begin{abstract}
Diabetes is a metabolic disorder with multiorgan complications, including reproductive system dysfunction where lipid imbalance of germ cells play an important role. $N$-stearoylethanolamine (NSE) shows a modulatory effect on the lipid composition under different pathologies. Therefore, the aim of our study was to investigate the NSE effect on the testes lipid composition and testosterone level in plasma of diabetic rats. Diabetes was induced in Sprague-Dawley rats by a single streptozotocin injection (50 mg/kg). Animals with glucose levels of 8-12 mmol/l were further selected. NSE was administrated to rats (50 mg/kg) for 10 days at 1.5 months after the streptozotocin injection. The rat testes were used for lipid analysis, namely, phospholipid level, fatty acid methyl esters and plasma testosterone estimation. NSE administration to diabetic rats triggered normalization of total and individual phospholipid content, as well as composition of free and phospholipids fatty acids in the rat testes. In addition, the testosterone content showed a slight increase under the action of NSE. Our results showed that the early stages of diabetes caused destructive changes in rat testes that may induce a decrease in future testicular function. NSE administration to diabetic rats normalized the lipid content of rat testes and was correlated with an increased testosterone level. NSE induced the restoration of testes structure and function during the early stages of streptozotocin-induced diabetes in rats.
\end{abstract}

Ke y w o r d s: streptozotocin-induced, diabetes mellitus, testes, $N$-stearoylethanolamine, phospholipids, fatty acids, testosterone.

\section{Introduction}

Diabetes is a complex systemic disease that underlies insulin deficiency, resulting in impaired carbohydrate metabolism. The main mechanism of damage to insulin-secreting cells, followed by diabetes development, is an autoimmune process initiated by proinflammatory cytokine IL-1. It is known that an increased production of this cytokine correlates with inflammatory and infectious processes. A long-term increase in its content causes a selective toxic effect on insulin-secreting cells followed by the overproduction of nitric oxide. Excessive amounts of nitric oxide inactivate aconitase (Krebs cycle enzyme), thereby disrupting glucose oxidation and ATP synthesis, as well as activate apoptosis of insulin-secreting pancreatic cells, causing breaks in DNA strands [1].

Modifications of the structural and functional state of cell membranes, associated with the lipid peroxidation process, play an important role in the pathogenesis of diabetes. Activation of lipid peroxidation triggers many destructive changes in the main organs, including the reproductive system.

Considering the great vulnerability of the male reproductive system, sexual disorders are considered to be one of the most widespread complications of diabetes, and more than 150 million people are affected worldwide. It is worthy of note, that the young

(C) 2020 Onopchenko O. V. et al. This is an open-access article distributed under the terms of the Creative Commons Attribution License, which permits unrestricted use, distribution, and reproduction in any medium, provided the original author and source are credited. 
reproductive male population is primarily affected by insulin-dependent diabetes.

The pathogenesis of sexual disorders in diabetic males is complex and multifunctional, and has not been fully studied. It is generally accepted that inhanced oxidative and nitrosative stress during type I diabetes causes development of testicular dysfunction, followed by decreased male fertility. In addition, diabetic complications induce structural and functional changes in the testes and reduce testosterone production [2]. Considering the increasing incidence of type I diabetes among the Ukrainian population, it is currently important to develop affordable medicines to treat infertility in diabetic males.

Today, a prooxidant-antioxidant imbalance, oxidative and nitrosative stress, inhanced lipid peroxidation, and protein and nucleic acid oxidative modifications play leading roles in the development of many diseases [3]. The formation of lipid peroxidation products mainly correlates with the activity of the antioxidant enzyme system, whose leading function is to maintain a stable level of reactive oxygen species in cells.

The primary targets of reactive oxygen and nitrogen species in animals are proteins and lipids of biological membranes. Lipids can initiate free radical reactions that cause oxidative damage of tissues and organs. Hydroperoxides and other products of free radical lipid oxidation can cause inactivation or transformation of membrane-bound and cytosolic enzymes, as well as protein modification and depolymerization of DNA, causing systemic damage [4].

Phospholipids (PL), in addition to their major structural function in cell membranes, work as bioregulators and mediators in many biochemical and physiological processes [5, 6]. Moreover, PL and fatty acids (FA) play an important role in adaptive reactions, regulating the fluidity and permeability of plasma membranes [5, 7]. FA affect numerous structural, metabolic and regulatory mechanisms in the cell, including signal transduction processes, and have direct and indirect effects on the activity of various genes, modifying mRNA and protein metabolism [8]. Discovery of the nuclear peroxisome proliferator-activated receptors (PPAR), whose endogenous ligands are FA, confirmed that FA and their metabolites can act as hormones, regulating activity and distribution of specific transcription factors [9].

Among the number of FA derivatives is the class of minor lipids - N-acylethanolamines (NAE)
- bioactive compounds with a wide spectrum of biological and pharmacological action including membrane protective, antioxidant, immunomodulatory, anti-inflammatory, anti-toxic, and adaptogenic properties [10-12]. The most studied compound among this class is anandamide ( $\mathrm{N}$-arachidonoylethanolamine), known as an endogenous ligand of cannabinoid receptors. Meanwhile, the focus of our studies have been NAE with saturated acyl chains, including N-stearoylethanolamine (NSE), that do not activate cannabinoid receptors, but however, exhibit a cannabimimetic effect [13]. It is important to note that NAE are synthesized in tissues under various damaging conditions, triggering the chain of reparative and adaptive processes in the body.

Our prior studies in the field of semen cryopreservation showed that the mixture of unsaturated and saturated NAE, added to the preservative solution, significantly increased sperm motility and fertilization ability via stabilization of sperm PL composition [14].

Therefore, considering the fact that development of male infertility during diabetes, as a consequence of impaired testes function during oxidative and nitrosative stress, may be associated with modifications of tissue lipid composition, the aim of this study was to investigate the influence of saturated NAE on testes lipid composition and plasma testosterone level in rats with streptozotocin-induced diabetes.

\section{Materials and Methods}

Experimental model of streptozotocin-induced diabetes in rats. The study was carried out on Sprague-Dawley rats (12-week-old males, 140$150 \mathrm{~g})$. All procedures were conducted in accordance with the rules of the Commission on Bioethics of the Palladin Institute of Biochemistry, National Academy of Sciences of Ukraine (Kyiv, Ukraine) that conforms to the National Institutes of Health Guidelines for Care and Use of Laboratory Animals. Rats were housed in standard cages with free access to food and water. This study was approved by the Ethics Committee of Palladin Institute of Biochemistry of NASU (11 May 2018, N 7).

Type I diabetes was induced by a single intraperitoneal injection of $\mathrm{Na}^{+}$-citrate streptozotocin solution (Sigma, Shanghai, China), $\mathrm{pH}$ 5.5, at a dose of $50 \mathrm{mg} / \mathrm{kg}$ of body weight. Development of diabetes in the experimental group was confirmed according to the results of the blood glucose level, 
measured within 2, 4 and 6 weeks of the streptozotocin injection with a standard domestic kit (Philisit Diagnostics, Dnepr, Ukraine), based on the glucose oxidase method [15]. At 1.5 months after the streptozotocin injection, animals with a blood glucose level of 8-12 $\mathrm{mmol} / \mathrm{l}$ were further selected and divided into 2 groups: Diabetes $(n=10)$ and Diabetes+NSE $(n=10)$. The Diabetes+NSE group received an aqueous suspension of NSE orally at a dose of $50 \mathrm{mg} /$ $\mathrm{kg}$ for 10 days, whereas the Diabetes group received pure water. Intact control animals were divided into Control $(n=7)$ and NSE $(n=7)$ groups. Rats from the NSE group were treated with NSE according to the same scheme as the Diabetes+NSE group, while animals from the Control group received water as a control for the NSE solvent. At the end of the experiment, animals were decapitated under nembutal anesthesia (50 mg/kg of body weight). Testes were immediately placed in liquid nitrogen and blood was collected in tubes with sodium citrate solution in the ratio of 4:1 (blood:citrate). The blood plasma was obtained by centrifugation at $300 \mathrm{~g}$ for $30 \mathrm{~min}$ at $4{ }^{\circ} \mathrm{C}$. Then blood plasma was collected and immediately frozen $\left(-20^{\circ} \mathrm{C}\right)$.

Testosterone level assay. The plasma total testosterone level was determined using a commercially available enzyme immunoassay kit (Granum, Kharkiv, Ukraine).

Phospholipid and fatty acid profile assay. Rat testes were homogenized in a physiological saline solution. Total lipids were extracted from $10 \%$ homogenate and purified by the methods of Bligh and Dyer [16]. The content of total PL, expressed by the level of inorganic phosphate [P(i)] in the lipid extracts, were assayed using the molybdenum blue staining method [17] and determined spectrophotometrically as the phosphomolybdenum blue complex in the 815-nm wavelength region.

The individual PL content was determined by lipid extract separation with 2D thin-layer chromatography. The solvent system for the first dimension was chloroform (65):methanol (30):ammonia (6), benzene $(10)(\mathrm{v} / \mathrm{v})$, and for the second dimension was chloroform (5):methanol (1):acetic acid (1):water (0.5):acetone (2) (v/v) [18, 19].

The level of individual PL was estimated by colorimetric measurement of the $\mathrm{P}(\mathrm{i})$ in each separated PL spot, using the Vaskovskiy and Kostetskiy method [17].

The FA composition of testes was investigated using a modified method of Carreau and Dubaco
[20]. The dried lipid extract was dissolved in benzene and transferred to an ampoule containing $3 \mathrm{M}$ $\mathrm{HCl}$ in methanol, sealed and heated for one hour. After cooling, methyl-rich esters were extracted with hexane, dehydrated with $\mathrm{Na}_{2} \mathrm{SO}_{4}$ and dried using a rotary evaporator. To separate the FA methyl esters (FAME) from cholesterol, the obtained lipid extract was fractionated using thin-layer chromatography in dehydrated benzene. The FAME zone was scraped and eluted from silica gel using hexane. The eluate was evaporated and stored in a low-temperature refrigerator at $-18^{\circ} \mathrm{C}$. The FAME were analyzed by gas-liquid chromatography. A Carlo Erba gas chromatograph (model HRGC 5300, Cornaredo, Italy, with flame ionization detector) equipped with a glass packed column (length: $3.5 \mathrm{~m}$, internal diameter: $3 \mathrm{~mm}$ ), completed with $10 \% \mathrm{SP}-2300$ phase (Silar 5CP, Bellefonte, USA) on "Chromosorb W/ HP" was used to separate FAME. The temperature was programmed from 140 to $250{ }^{\circ} \mathrm{C}$ at $2{ }^{\circ} \mathrm{C} / \mathrm{min}$. The FAME were identified by comparing the retention time of each peak with FAME standards (Sigma Serva, Darmstadt, Germany). The relative amount was quantified by integrating the area under the specific peak and dividing the results by the total area for all FA.

Statistical analysis. The data, presented as mean values $(M) \pm$ standard errors of the means (SEM), were compared using Student's unpaired $t$-test. The differences were considered significant at $P<0.05$.

\section{Results}

During the experiment, the diabetes progression was examined by measuring changes in the blood glucose level of the rats. As shown in Fig. 1, at 6 weeks after diabetes induction the blood glucose content was $9-10 \mathrm{mmol} / \mathrm{L}$ that corresponded to the initial stages of the disease.

As seen in Fig. 2, there was a considerable and significant decrease of testosterone content (from $10.906 \pm 2.47$ to $0.251 \pm 0.01 \mathrm{nmol} / \mathrm{l}$, Control group vs Diabetes group, respectively; $P=0.0007$ ) in plasma of diabetics rats at the end of the experiment. NSE administration promoted a slight increase (from $0.251 \pm 0.01$ to $0.49 \pm 0.07 \mathrm{nmol} / \mathrm{l}$, Diabetes group vs Diabetes+NSE group, respectively; $P=0.0061$ ) in testosterone content in plasma of rats with streptozotocin-induced diabetes. Administration of NSE to the control rats (Control+NSE group) did not appreciably change the plasma testosterone content. 


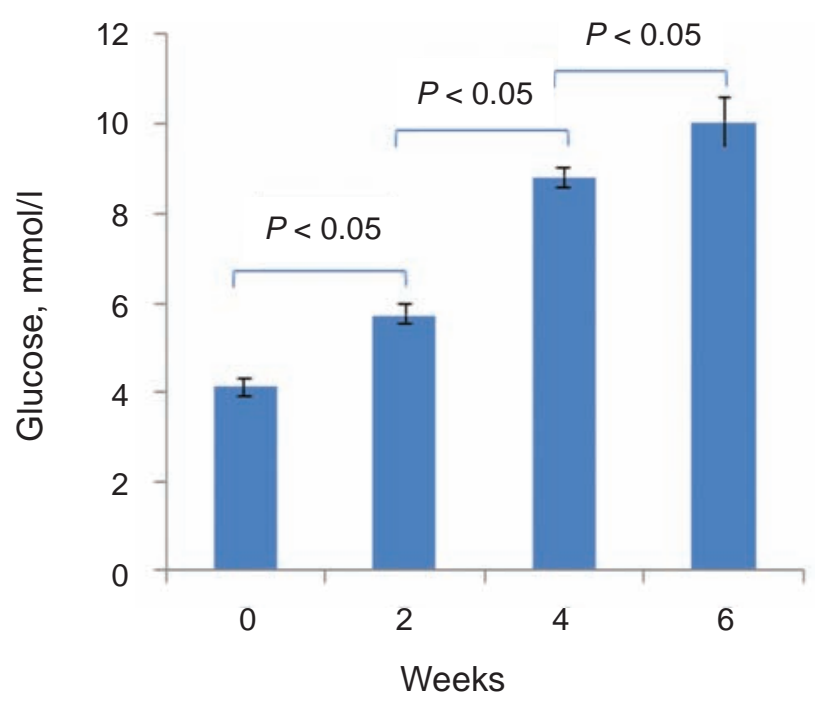

Fig. 1. Blood glucose level in rats. Values represented as mean $\pm \operatorname{SEM}(n=20)$

There was a significant increase in the content of total lipids in testes of diabetic rats (from $25.024 \pm 2.633$ to $35.847 \pm 1.472 \mathrm{mg} / \mathrm{g}$, Control group vs Diabetes group, respectively; $P=0.0059$ ) and under NSE treatment (from 35.847 \pm 1.472 to $39.066 \pm 1.735 \mathrm{mg} / \mathrm{g}$, Diabetes group vs Diabetes+NSE group, respectively; $P=0.0012$ ) (Fig. 3).

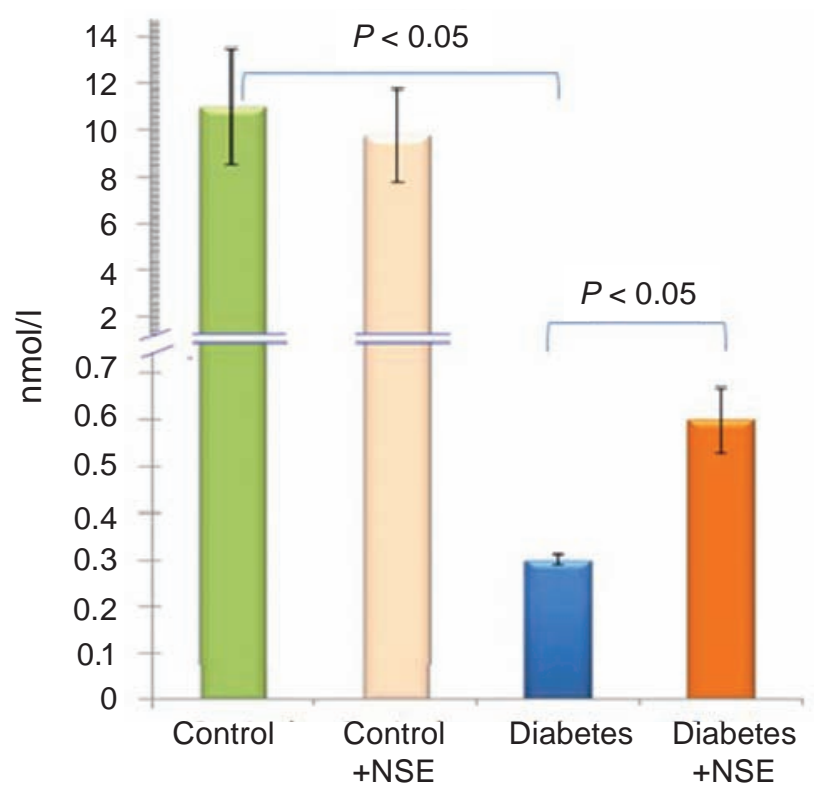

Fig. 2. Plasma testosterone level in rats. Values represented as mean \pm SEM. For each control group $n=7$. For each diabetic group $n=10$. NSE $-N$ stearoylethanolamine
However, the content of total PL in testes of diabetic rats significantly decreased, measured as per gram of tissue (from $5.575 \pm 0.698$ to $2.397 \pm 0.907 \mu \mathrm{g}$ $\mathrm{P}_{\mathrm{i}} / \mathrm{g}$, Control group vs Diabetes group, respectively; $P=0.0168$ ) (Fig. 4, A) and per mg of lipids (from $0.209 \pm 0.036$ to $0.068 \pm 0.024 \mu \mathrm{g} \mathrm{P}_{\mathrm{i}} / \mathrm{mg}$, Control group vs Diabetes group, respectively; $P=0.0068$ ) (Fig. 4 , $B)$.

NSE administration to diabetics rats resulted in normalization of total PL in testes, measured as per gram of tissue (from 2.397 \pm 0.907 to $6.195 \pm 0.805 \mu \mathrm{g}$ $\mathrm{P}_{\mathrm{i}} / \mathrm{g}$, Diabetes group vs Diabetes+NSE group, respectively; $P=0.0073$ ) (Fig. $4, A$ ) and per $\mathrm{mg}$ of lipids (from $0.068 \pm 0.024$ to $0.213 \pm 0.057 \mu \mathrm{g} \mathrm{P}_{\mathrm{i}} / \mathrm{mg}$, Diabetes group vs Diabetes+NSE group, respectively; $P=0.0364$ ) (Fig. 4, B). Administration of NSE to control rats (NSE group) did not appreciably change the content of total PL in rat testes (Fig. 4, A, B).

For further investigation of the PL composition in rat testes, we used 2D thin-layer chromatography. Fig. 5 shows a typical picture of the chromatographic separation of individual PL in rat testes.

Results of chromatographic analysis showed that diabetes caused a reduction in the content of main phospholipids, namely, phosphatidylcholine (PC), phosphatidylethanolamine (PE), diphosphatidylglycerol (DPG), sphingomyelin (SM), phosphati-

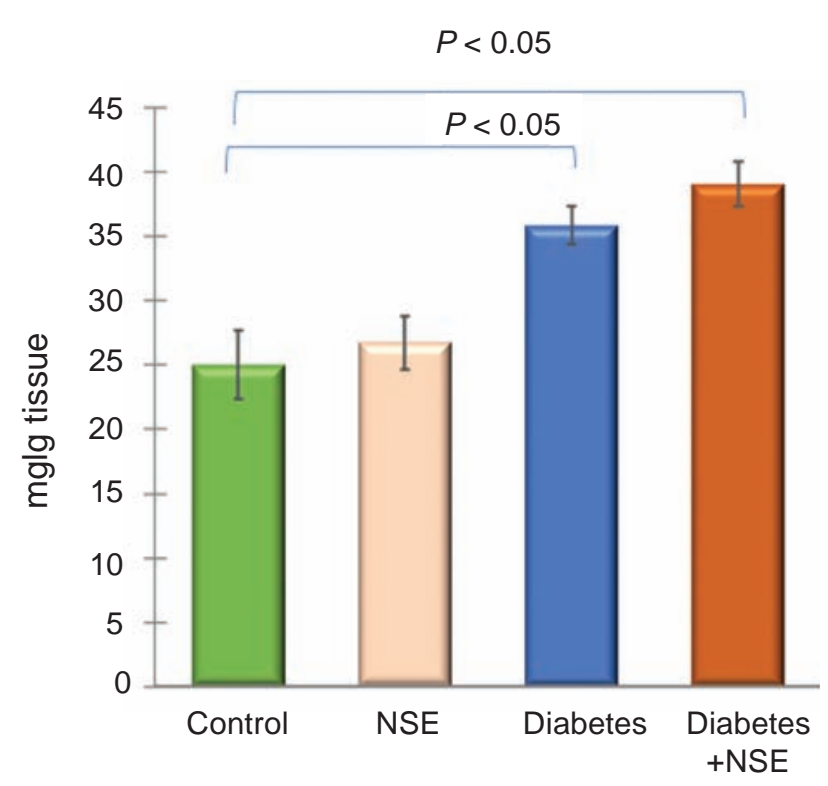

Fig. 3. Total lipid content in rat testes (mg of lipids per $g$ of tissue). Values represented as mean \pm SEM. For control group and NSE group $n=7$. For each diabetic group $n=10$. NSE $-N$-stearoylethanolamine 
$A$

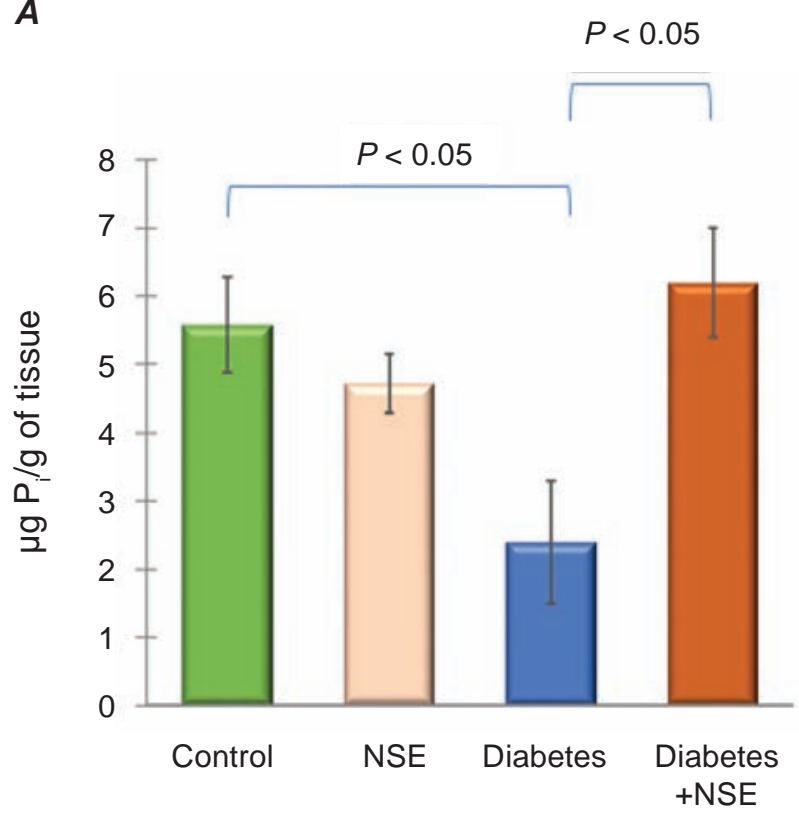

B

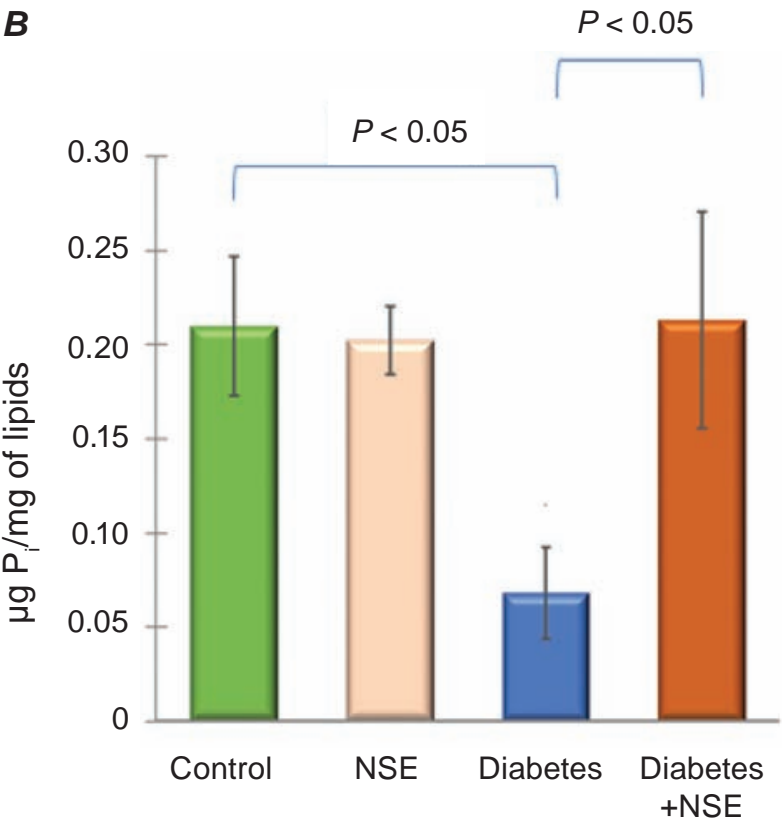

Fig. 4. Total phospholipid content in rat testes (A) - as $\mu g P_{i}$ per $g$ of tissue; (B) - as $m g$ Per $m g$ of lipids. Values represented as mean \pm SEM. For control group and NSE group $n=7$. For each diabetic group $n=10$. $N S E$ - N-stearoylethanolamine

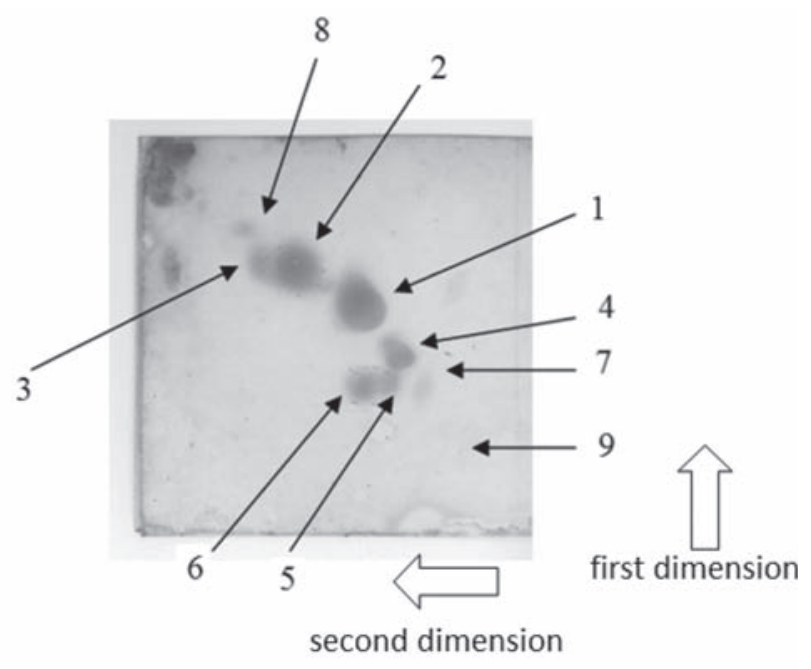

Fig. 5. Typical chromatographic separation of individual phospholipids in control group rat testes, using 2D thin-layer chromatography. 1 - phosphatidylcholine; 2 - phosphatidylethanolamine; 3 - diphosphatidylglycerol; 4 - sphingomyelin; 5 phosphatidylinositol; 6 - phosphatidylserine; 7 lysophosphatidylcholine; 8 - non-identified phospholipids; 9 - starting point

dylinositol (PI), phosphatidylserine (PS), lysophosphatidylcholine (LPC) (Table 1, 2). The NSE treatment of diabetic rats promoted the restoration of particular phospholipids level.
Analysis of FA composition in testes of diabetic rats showed an increase in the content of saturated FA ( $P=0.0139$, Table $3 ; P=0.0003$, Table 5) and a decrease in the content of unsaturated FA ( $P=0.0193$, Table 3; $P=0.0001$, Table 5) in the pool of free and PL FA. Specifically, the increase was found in the level of following saturated FA: caproic ( $P=0.0136$, Table 4), tridecylic $(P=0.0065$, Table 4; $P=0.0017$, Table 6$)$, pentadecanoic $(P=0.0143$, Table 4; $P=0.0002$, Table 6$)$, palmitic $(P=0.0232$, Table $4 ; P=0.00003$, Table 6$)$ and behenic $(P=0.0092$, Table 4).

The changes that followed led to an increase in the saturation index (the ratio of saturated/unsaturated FA) $(P=0.0183$, Table $3 ; P=0.0007$, Table 5) in PL FA and free FA.

The imbalance in the content of unsaturated FA in diabetic rats occured mainly due to the decrease in the content of monounsaturated FA (lauroleic $(P=0.0185$, Table 6$)$, palmitovaccenic $(P=0.0001$, Table 6), oleic $(P=0.0211$, Table 6$))$, diunsaturated FA (docosadienoic $(P=0.000004$, Table 6)) and polyunsaturated FA (adrenic $(P=0.0071$, Table 4 ; $P=0.0044$, Table 6$)$; osbond $(P=0.005$, Table 4$)$; docosaheanoic $(P=0.0005$, Table 6$)$ ) in PL FA (Table 4) and free A (Table 6).

The NSE treatment of diabetic rats restored content of saturated FA (pentadecanoic $(P=0.0001$, Ta- 
Ta ble 1. The level of inorganic phosphorus $\left(P_{i}\right)$ in individual phospholipids per gram of tissue in testes of rats with streptozotocin-induced diabetes and after N-stearoylethanolamine (NSE) treatment

\begin{tabular}{l|c|c|c|c}
\hline \multirow{2}{*}{ Phospholipid, $\mu g$ P /g of tissue } & \multicolumn{4}{|c}{ Group } \\
\cline { 2 - 5 } & Control & NSE & Diabetes & Diabetes+ NSE \\
\hline Phosphatidylcholine (PC) & $2.22 \pm 0.20$ & $1.88 \pm 0.21$ & $0.89 \pm 0.37^{*}$ & $2.58 \pm 0.53^{\#}$ \\
Phosphatidylethanolamine (PE) & $1.86 \pm 0.23$ & $1.32 \pm 0.14$ & $0.81 \pm 0.27^{*}$ & $1.79 \pm 0.27^{\#}$ \\
Diphosphatidylglycerol (DPG) & $0.32 \pm 0.05$ & $0.18 \pm 0.03^{*}$ & $0.15 \pm 0.04^{*}$ & $0.30 \pm 0.05^{\#}$ \\
Sphingomyelin (SM) & $0.48 \pm 0.09$ & $0.45 \pm 0.11$ & $0.24 \pm 0.08$ & $0.56 \pm 0.11^{\#}$ \\
Phosphatidylinositol (PI) & $0.28 \pm 0.06$ & $0.19 \pm 0.03$ & $0.11 \pm 0.03^{*}$ & $0.27 \pm 0.06^{\#}$ \\
Phosphatidylserine (PS) & $0.30 \pm 0.03$ & $0.20 \pm 0.03^{*}$ & $0.11 \pm 0.04^{*}$ & $0.28 \pm 0.05^{\#}$ \\
Lysophosphatidylcholine (LPC) & $0.06 \pm 0.03$ & $0.06 \pm 0.009$ & $0.03 \pm 0.01$ & $0.16 \pm 0.04^{\#}$ \\
Non-identified & $0.08 \pm 0.04$ & $0.05 \pm 0.02$ & $0.01 \pm 0.005$ & $0.12 \pm 0.04^{\#}$ \\
Starting point & $0.13 \pm 0.04$ & $0.06 \pm 0.01$ & $0.02 \pm 0.007^{*}$ & $0.11 \pm 0.02^{\#}$ \\
\hline
\end{tabular}

Mean values \pm standard errors of the means. For control group and NSE group $n=7$. For each diabetic group $n=10$. $* P<0.05$, Diabetes group vs Control group; ${ }^{*} P<0.05$, Diabetes+NSE group vs Diabetes group. $\mu g P_{i} / g$ of tissue - the concentration of phospholipids was estimated as $\mu$ g of inorganic phosphorus in g of tissue; NSE - N-stearoylethanolamine

Ta b le 2. The level of inorganic phosphorus $\left(P_{i}\right)$ in individual phospholipids per $\mathrm{mg}$ of lipids in testes of rats with streptozotocin-induced diabetes and after $N$-stearoylethanolamine (NSE) treatment

\begin{tabular}{l|c|c|c|c}
\hline \multirow{2}{*}{ Phospholipid, $\mu g$ P /mg lipids } & \multicolumn{3}{|c}{ Group } \\
\cline { 2 - 5 } & Control & NSE & Diabetes & Diabetes+ NSE \\
\hline Phosphatidylcholine (PC) & $0.09 \pm 0.02$ & $0.07 \pm 0.01$ & $0.04 \pm 0.01^{*}$ & $0.09 \pm 0.03^{\#}$ \\
Phosphatidylethanolamine (PE) & $0.06 \pm 0.01$ & $0.05 \pm 0.007$ & $0.02 \pm 0.009^{*}$ & $0.06 \pm 0.02^{\#}$ \\
Diphosphatidylglycerol (DPG) & $0.02 \pm 0.005$ & $0.007 \pm 0.0009$ & $0.004 \pm 0.001^{*}$ & $0.01 \pm 0.003^{\#}$ \\
Sphingomyelin (SM) & $0.02 \pm 0.005$ & $0.02 \pm 0.003$ & $0.007 \pm 0.002$ & $0.02 \pm 0.003^{\#}$ \\
Phosphatidylinositol (PI) & $0.01 \pm 0.002$ & $0.008 \pm 0.001$ & $0.004 \pm 0.0009^{*}$ & $0.008 \pm 0.0001^{\#}$ \\
Phosphatidylserine (PS) & $0.01 \pm 0.002$ & $0.008 \pm 0.001$ & $0.003 \pm 0.001^{*}$ & $0.01 \pm 0.003^{\#}$ \\
Lysophosphatidylcholine (LPC) & $0.003 \pm 0.001$ & $0.003 \pm 0.0004$ & $0.001 \pm 0.0003$ & $0.005 \pm 0.002^{\#}$ \\
Non-identified & $0.003 \pm 0.002$ & $0.001 \pm 0.0004$ & $0.0004 \pm 0.0002$ & $0.004 \pm 0.0009^{\#}$ \\
Starting point & $0.004 \pm 0.001$ & $0.01 \pm 0.011$ & $0.0004 \pm 0.0001^{*}$ & $0.003 \pm 0.0007^{\#}$ \\
\hline
\end{tabular}

Mean values \pm standard errors of the means. For control group and NSE group $n=7$. For each diabetic group $n=10$. ${ }^{*} P<0.05$, Diabetes group vs Control group; ${ }^{\#} P<0.05$, Diabetes+NSE group vs Diabetes group. $\mu \mathrm{g} \mathrm{Pi} / \mathrm{mg}$ lipids - the concentration of phospholipids was estimated as $\mu \mathrm{g}$ of inorganic phosphorus in mg of lipid extract; NSE - N-stearoylethanolamine

ble 6); palmitic ( $P=0.0003$, Table 6); heneicosanoic $(P=0.0018$, Table 6)), monounsaturated FA (gondoic $(P=0.0023$, Table 4; $P=0.0003$, Table 6$)$; oleic $(P=0.0104$, Table 6$))$ and di- or polyunsaturated FA (linoleic $(P=0.0048$, Table 4$)$; docosadienoic $(P=0.00001$, Table 6); adrenic $(P=0.0028$, Table 4; $P=0.0166$, Table 6); docosahexanioc $(P=0.0057$, Table 6)) in PL FA (Table 4) and free FA (Table 6).
The results of FA ratio estimation presented in Fig. 6 showed that diabetes caused an increase in the ratio of oleic to stearic acid ( $P=0.0045$; Fig. $6, B)$ in PL FAs, while there were no significant changes in the ratio of linolenic/linoleic acid (Fig. 6, A). The NSE treatment of diabetic rats restored the ratio of oleic to stearic acid ( $P=0.0038$; Fig. $6, B)$ in PL FA and decreased the ratio of oleic to stearic acid $(P=0.0014$; Fig. $6, B)$ in free FA. 
Ta ble 3. Saturation of fatty acids in phospholipids (\% of total fatty acid level) from testes of rats with streptozotocin-induced diabetes and after $N$-stearoylethanolamine (NSE) treatment

\begin{tabular}{l|c|c|c|c}
\hline \multirow{2}{*}{\multicolumn{1}{c}{ Fatty acid }} & \multicolumn{4}{|c}{ Group } \\
\cline { 2 - 5 } & Control 1 & NSE 2 & Diabetes 3 & Diabetes+ NSE 4 \\
\hline Saturated, $\Sigma$ & $38.98 \pm 0.95$ & $43.13 \pm 1.08^{*}$ & $42.44 \pm 1.01^{*}$ & $41.3 \pm 0.69$ \\
Unsaturated, $\Sigma$ & $59.77 \pm 1.05$ & $55.47 \pm 1.05^{*}$ & $56.46 \pm 0.96^{*}$ & $57.27 \pm 0.71$ \\
Saturated/Unsaturated & $0.60 \pm 0.06$ & $0.78 \pm 0.04^{*}$ & $0.75 \pm 0.03^{*}$ & $0.72 \pm 0.02$ \\
Monounsaturated, $\Sigma$ & $18.79 \pm 0.27$ & $19.24 \pm 0.32$ & $19.86 \pm 0.35^{*}$ & $19.73 \pm 0.36$ \\
Diunsaturated, $\Sigma$ & $6.68 \pm 0.45$ & $5.17 \pm 0.19^{*}$ & $5.61 \pm 0.21$ & $6.49 \pm 0.19^{*}$ \\
Polyunsaturated, $\Sigma$ & $34.29 \pm 1.05$ & $31.05 \pm 0.91^{*}$ & $30.99 \pm 1.21$ & $31.04 \pm 0.79^{*}$ \\
Non-identified, $\Sigma$ & $1.04 \pm 0.26$ & $1.40 \pm 0.20$ & $1.01 \pm 0.06$ & $1.44 \pm 0.08^{\#}$
\end{tabular}

Mean values \pm standard errors of the means. For control group and NSE group $n=7$. For each diabetic group $n=10 . * P$ $<0.05$, Diabetes group vs Control group; ${ }^{\#} P<0.05$, Diabetes+NSE group vs Diabetes group. $\Sigma-$ mathematical summation of particular group of FA

Ta ble 4. Phospholipid fatty acid composition (\% of total fatty acid level) in testes of rats with streptozotocin-induced diabetes and after $N$-stearoylethanolamine (NSE) treatment

\begin{tabular}{l|c|c|c|c}
\hline \multirow{2}{*}{\multicolumn{1}{c}{ Fatty acid }} & \multicolumn{4}{c}{ Group } \\
\cline { 2 - 5 } & Control 1 & NSE 2 & Diabetes 3 & Diabetes+ NSE 4 \\
\hline Valeric (5:0) & $0.033 \pm 0.011$ & 0.032 & - & 0.032 \\
Caproic (6:0) & $0.041 \pm 0.006$ & 0.032 & $0.064 \pm 0.006^{*}$ & $0.051 \pm 0.008$ \\
Heptanoic(7:1) & $0.057 \pm 0.013$ & $0.073 \pm 0.006$ & $0.047 \pm 0.016$ & $0.053 \pm 0.012$ \\
Caprylic (8:0) & $0.039 \pm 0.011$ & $0.054 \pm 0.006$ & $0.058 \pm 0.006$ & $0.043 \pm 0.005$ \\
Capric acid (10:0) & $0.027 \pm 0.005$ & $0.037 \pm 0.004$ & $0.034 \pm 0.003$ & $0.037 \pm 0.008$ \\
Undecylic (11:0) & $0.024 \pm 0.004$ & $0.031 \pm 0.003$ & $0.028 \pm 0.002$ & $0.039 \pm 0.008$ \\
Lauric (12:0) & $0.045 \pm 0.005$ & $0.056 \pm 0.007$ & $0.061 \pm 0.006$ & $0.089 \pm 0.018^{*}$ \\
Iso-Lauric (12:0) & $0.026 \pm 0.005$ & $0.028 \pm 0.002$ & $0.031 \pm 0.004$ & $0.033 \pm 0.004$ \\
Lauroleic (12:1) & $0.026 \pm 0.004$ & $0.039 \pm 0.006$ & $0.047 \pm 0.013$ & $0.045 \pm 0.008$ \\
Tridecylic (13:0) & $0.067 \pm 0.008$ & $0.104 \pm 0.011^{*}$ & $0.094 \pm 0.005^{*}$ & $0.110 \pm 0.024$ \\
Myristic (14:0) & $0.280 \pm 0.032$ & $0.280 \pm 0.026$ & $0.340 \pm 0.026$ & $0.365 \pm 0.037$ \\
Myristovaccenic (14:1) & $0.172 \pm 0.023$ & $0.185 \pm 0.015$ & $0.208 \pm 0.018$ & $0.245 \pm 0.046$ \\
Myristolinoleic (14:2) & $0.082 \pm 0.014$ & $0.051 \pm 0.009$ & $0.057 \pm 0.010$ & $0.057 \pm 0.011$ \\
Pentadecanoic (15:0) & $0.141 \pm 0.017$ & $0.249 \pm 0.100$ & $0.185 \pm 0.006^{*}$ & $0.252 \pm 0.036^{*}$ \\
Palmitic (16:0) & $20.249 \pm 0.721$ & $25.465 \pm 1.042^{*}$ & $23.267 \pm 1.153^{*}$ & $22.408 \pm 0.779$ \\
Iso-Palmitic (16:0) & $3.582 \pm 0.437$ & $3.051 \pm 0.594$ & $3.953 \pm 0.656$ & $2.735 \pm 0.643$ \\
Palmitovaccenic (16:1) & $1.357 \pm 0.101$ & $1.199 \pm 0.087$ & $1.339 \pm 0.103$ & $1.237 \pm 0.041$ \\
Heptadecanoic (17:0) & $0.387 \pm 0.020$ & $0.295 \pm 0.013^{*}$ & $0.379 \pm 0.025$ & $0.528 \pm 0.02^{* \#}$ \\
Stearic (18:0) & $12.453 \pm 0.246$ & $11.604 \pm 0.269 *$ & $12.046 \pm 0.157$ & $13.060 \pm 0.175^{\#}$ \\
Iso-Stearic (18:0) & $1.097 \pm 0.120$ & $0.854 \pm 0.152$ & $1.103 \pm 0.177$ & $0.907 \pm 0.218$ \\
Oleic (18:1) & $15.635 \pm 0.252$ & $15.860 \pm 0.336$ & $16.689 \pm 0.447$ & $16.519 \pm 0.315$ \\
Linoleic (18:2n-6) & $6.136 \pm 0.490$ & $4.683 \pm 0.163^{*}$ & $5.334 \pm 0.190$ & $6.161 \pm 0.190^{\#}$ \\
Lenolenic (18:3n-6) & $0.051 \pm 0.008$ & $0.091 \pm 0.022$ & $0.053 \pm 0.018$ & $0.083 \pm 0.019$ \\
Arachidic (20:0) & $0.216 \pm 0.013$ & $0.236 \pm 0.023$ & $0.157 \pm 0.017 *$ & $0.271 \pm 0.02^{* \#}$ \\
\hline
\end{tabular}




\section{Table 4. (Continuation)}

\begin{tabular}{l|c|c|c|c}
\hline \multirow{2}{*}{\multicolumn{1}{c}{ Fatty acid }} & \multicolumn{4}{|c}{ Group } \\
\cline { 2 - 5 } & Control 1 & NSE 2 & Diabetes 3 & Diabetes+ NSE 4 \\
\hline Gondoic (20:1) & $0.537 \pm 0.045$ & $0.557 \pm 0.028$ & $0.491 \pm 0.024$ & $0.624 \pm 0.030^{\#}$ \\
Eicosadienoic (20:2n-6) & $0.104 \pm 0.058$ & $0.039 \pm 0.005$ & $0.043 \pm 0.009$ & $0.035 \pm 0.003$ \\
Eicosatrienoic (20:3n-6) & $0.243 \pm 0.041$ & $0.179 \pm 0.021$ & $1.259 \pm 1.074$ & $0.300 \pm 0.010$ \\
Arachidonic (20:4n-6) & $15.916 \pm 0.910$ & $15.872 \pm 0.537$ & $15.835 \pm 0.520$ & $14.940 \pm 0.233$ \\
Behenic (22:0) & $0.378 \pm 0.049$ & $0.802 \pm 0.053^{*}$ & $0.747 \pm 0.026^{*}$ & $0.332 \pm 0.026$ \\
Erucic (22:1n-9) & $0.760 \pm 0.098$ & $1.048 \pm 0.055^{*}$ & $0.750 \pm 0.067$ & $0.686 \pm 0.038$ \\
Docosadienoic (22:2n-6) & $0.407 \pm 0.103$ & $0.555 \pm 0.074$ & $0.275 \pm 0.018$ & $0.252 \pm 0.024$ \\
Adrenic (22:4n-6) & $0.327 \pm 0.029$ & $0.402 \pm 0.041$ & $0.233 \pm 0.016^{*}$ & $0.314 \pm 0.018^{\#}$ \\
Osbond (22:5n-6) & $16.407 \pm 0.615$ & $13.845 \pm 0.601^{*}$ & $13.220 \pm 0.847^{*}$ & $15.211 \pm 1.200$ \\
Docosahexaenic (22:6n-6) & $9.224 \pm 8.310$ & $2.248 \pm 1.167$ & $5.335 \pm 2.342$ & $4.848 \pm 1.820$ \\
Non-identified & $0.149 \pm 0.032$ & $0.175 \pm 0.031$ & $0.125 \pm 0.023$ & $0.180 \pm 0.027$
\end{tabular}

Mean values \pm standard errors of the means. For control group and NSE group $n=7$. For each diabetic group $n=10$. ${ }^{*} P<0.05$, Diabetes group vs Control group; ${ }^{~} P<0.05$, Diabetes+NSE group vs Diabetes group

Table 5. Saturation of free fatty acids (\% of total fatty acid level) in testes of rats with streptozotocininduced diabetes and after $N$-stearoylethanolamine (NSE) treatment

\begin{tabular}{l|c|c|c|c}
\hline \multirow{2}{*}{\multicolumn{1}{c|}{ Fatty acid }} & \multicolumn{4}{c}{ Group } \\
\cline { 2 - 5 } & Control 1 & NSE 2 & Diabetes 3 & Diabetes+ NSE 4 \\
\hline Saturated, $\Sigma$ & $29.85 \pm 0.41$ & $29.78 \pm 0.45$ & $44.60 \pm 3.25^{*}$ & $35.17 \pm 0.23^{* *}$ \\
Unsaturated, $\Sigma$ & $68.98 \pm 0.47$ & $69.20 \pm 0.45$ & $53.75 \pm 2.99^{*}$ & $63.77 \pm 0.32^{* *}$ \\
Saturated/Unsaturated & $0.43 \pm 0.01$ & $0.43 \pm 0.01$ & $0.86 \pm 0.10^{*}$ & $0.55 \pm 0.006^{* \#}$ \\
Monounsaturated, $\Sigma$ & $33.33 \pm 1.30$ & $35.50 \pm 0.38$ & $22.87 \pm 2.28^{*}$ & $29.77 \pm 0.38^{* \#}$ \\
Diunsaturated, $\Sigma$ & $22.46 \pm 0.60$ & $22.29 \pm 0.51$ & $11.43 \pm 1.29 *$ & $24.69 \pm 0.68^{* \#}$ \\
Polyunsaturated, $\Sigma$ & $13.19 \pm 1.46$ & $11.41 \pm 0.69$ & $19.45 \pm 5.37$ & $9.32 \pm 0.90^{*}$ \\
Non-identified, $\Sigma$ & $1.17 \pm 0.19$ & $1.01 \pm 0.13$ & $1.64 \pm 0.47$ & $1.05 \pm 0.17$ \\
\hline
\end{tabular}

Mean values \pm standard errors of the means. For control group and NSE group $n=7$. For each diabetic group $n=10 . * P$ $<0.05$, Diabetes group vs Control group; ${ }^{*} P<0.05$, Diabetes+NSE group vs Diabetes group. $\Sigma$ - mathematical summation of particular group of FA

\section{Discussion}

Earlier findings suggest that NAE in human reproductive fluids may regulate multiple physiological and pathological processes in the reproductive system, and exogenous cannabinoids administration, including oleylethanolamine, palmitoylethanolamine and NSE may affect these processes [21]. Moreover, PEA and OEA levels in human seminal plasma may reflect overall male reproductive health, playing a crucial role in the preservation of normal sperm function, including viability, motility and mitochondrial activity [22].
Considering that one of the main complications of diabetic pathogeneses is impaired male reproductive function, it is interesting to explore the biological effect and molecular mechanism of action for another prevailing NAE, namely NSE, during diabetes type I development.

Various studies describe a number of experimental approaches for the modulation of diabetes. In our experiment, we used a streptozotocin-induced experimental model of diabetes in rats, since it is currently the most widely used model among the chemically-induced group. In many cases, the nature 
Ta ble 6. Phospholipids fatty acid composition (\% of total fatty acid level) in testes of rats with streptozotocin-induced diabetes and after $N$-stearoylethanolamine (NSE) treatment

\begin{tabular}{|c|c|c|c|c|}
\hline \multirow{2}{*}{ Fatty acid } & \multicolumn{4}{|c|}{ Group } \\
\hline & Control 1 & NSE 2 & Diabetes 3 & Diabetes+ NSE 4 \\
\hline Lauric (12:0) & $0.081 \pm 0.011$ & $0.081 \pm 0.011$ & $0.061 \pm 0.009$ & $0.133 \pm 0.017^{* \#}$ \\
\hline Iso-Lauric (12:0) & - & - & 0.02 & $0.013 \pm 0.008$ \\
\hline Lauroleic (12:1) & $0.018 \pm 0.003$ & $0.018 \pm 0.002$ & $0.048 \pm 0.012 *$ & $0.022 \pm 0.006$ \\
\hline Tridecylic (13:0) & $0.009 \pm 0.0001$ & $0.015 \pm 0.003$ & $0.052 \pm 0.011^{*}$ & $0.014 \pm 0.002^{* \#}$ \\
\hline Myristic (14:0) & $1.242 \pm 0.099$ & $1.501 \pm 0.15$ & $1.312 \pm 0.064$ & $1.104 \pm 0.107$ \\
\hline Iso-Myristic (14:0) & $0.012 \pm 0.002$ & $0.015 \pm 0.002$ & $0.06 \pm 0.02 *$ & $0.022 \pm 0.011$ \\
\hline Myristovaccenic (14:1) & $0.142 \pm 0.021$ & $0.186 \pm 0.02$ & $0.198 \pm 0.027$ & $0.099 \pm 0.032^{\#}$ \\
\hline Pentadecanoic (15:0) & $0.496 \pm 0.052$ & $0.495 \pm 0.055$ & $0.226 \pm 0.023^{*}$ & $0.494 \pm 0.05^{\#}$ \\
\hline Palmitic (16:0) & $19.28 \pm 0.774$ & $20.65 \pm 0.942$ & $36.27 \pm 2.783^{*}$ & $19.94 \pm 0.886^{\#}$ \\
\hline Iso-Palmitic (16:0) & $0.117 \pm 0.017$ & $0.134 \pm 0.021$ & $0.425 \pm 0.194$ & $0.123 \pm 0.031$ \\
\hline Palmitovaccenic (16:1) & $7.094 \pm 0.77$ & $8.923 \pm 0.547$ & $2.569 \pm 0.425^{*}$ & $3.187 \pm 0.353^{*}$ \\
\hline Heptadecanoic (17:0) & $0.536 \pm 0.058$ & $0.441 \pm 0.051$ & $0.24 \pm 0.031 *$ & $0.803 \pm 0.066^{* \#}$ \\
\hline Stearic (18:0) & $6.986 \pm 0.827$ & $5.458 \pm 0.434$ & $4.625 \pm 0.532 *$ & $11.38 \pm 0.668^{* \#}$ \\
\hline Iso-Stearic (18:0) & - & - & 0.033 & 0.029 \\
\hline Oleic (18:1) & $23.64 \pm 0.89$ & $24.4 \pm 0.786$ & $18.7 \pm 1.792^{*}$ & $23.92 \pm 0.806^{\#}$ \\
\hline Linoleic (18:2n-6) & $17.13 \pm 2.808$ & $19.7 \pm 1.633$ & $11.1 \pm 1.322$ & $15.8 \pm 3.286$ \\
\hline Lenolenic (18:3n-6) & $0.789 \pm 0.118$ & $0.796 \pm 0.112$ & $0.258 \pm 0.15^{*}$ & $0.935 \pm 0.138^{\#}$ \\
\hline Arachidic (20:0) & $0.251 \pm 0.034$ & $0.166 \pm 0.013$ & $0.185 \pm 0.045$ & $0.464 \pm 0.031^{* \#}$ \\
\hline Gondoic (20:1) & $1.499 \pm 0.164$ & $1.295 \pm 0.128$ & $0.67 \pm 0.076^{*}$ & $1.638 \pm 0.198^{\#}$ \\
\hline Eicosadienoic (20:2n-6) & - & - & $0.214 \pm 0.08$ & - \\
\hline Eicosatrienoic (20:3n-6) & $0.55 \pm 0.084$ & $0.48 \pm 0.056$ & $0.472 \pm 0.179$ & $0.672 \pm 0.098$ \\
\hline Arachidonic (20:4n-6) & $5.082 \pm 0.75$ & $3.848 \pm 0.364$ & $11.11 \pm 4.582$ & $3.282 \pm 0.23 *$ \\
\hline Heneicosanoic (C21:0) & $0.843 \pm 0.106$ & $0.816 \pm 0.102$ & $0.27 \pm 0.063 *$ & $0.624 \pm 0.076^{\#}$ \\
\hline Behenic (22:0) & - & 0.233 & $0.874 \pm 0.177$ & 0.585 \\
\hline Erucic (22:1n-9) & $0.455 \pm 0.039$ & $0.218 \pm 0.047$ & $0.468 \pm 0.069$ & $0.552 \pm 0.098$ \\
\hline Docosadienoic $(22: 2 n-6)$ & $0.64 \pm 0.062$ & $0.591 \pm 0.165$ & $0.122 \pm 0.019 *$ & $0.754 \pm 0.093^{\#}$ \\
\hline Adrenic (22:4n-6) & $0.037 \pm 0.004$ & $0.063 \pm 0.008$ & $0.201 \pm 0.055^{*}$ & $0.063 \pm 0.024^{\#}$ \\
\hline Osbond $(22: 5 n-6)$ & $3.013 \pm 0.704$ & $2.797 \pm 0.502$ & $3.747 \pm 1.096$ & $1.828 \pm 0.416$ \\
\hline Docosahexaenic (22:6n-6) & $0.46 \pm 0.085$ & $0.407 \pm 0.071$ & $0.121 \pm 0.021^{*}$ & $0.377 \pm 0.088^{\#}$ \\
\hline Non-identified & $0.348 \pm 0.061$ & $0.357 \pm 0.05$ & $0.658 \pm 0.146$ & $0.247 \pm 0.036^{\#}$ \\
\hline
\end{tabular}

Mean values \pm standard errors of the means. For control group and NSE group $n=7$. For each diabetic group $n=10$. ${ }^{*} P<0.05$, Diabetes group vs Control group; ${ }^{*} P<0.05$, Diabetes+NSE group vs Diabetes group

and course characteristics of experimental modeling are consistent with human insulin-dependent diabetes, while streptozotocin itself is a glucosamine-nitrosourea compound that causes damage to the DNA of pancreatic cells, activating poly(ADP-ribose) polymerase (PARP) which is important for diabetes development [23].
In addition, a considerable decrease of plasma testosterone content was found at the end of experiment, suggesting a correlation between progression of diabetes and testosterone depletion. Meanwhile, the use of NSE promoted a slight increase in testosterone content in the plasma of the rats with diabetes. 

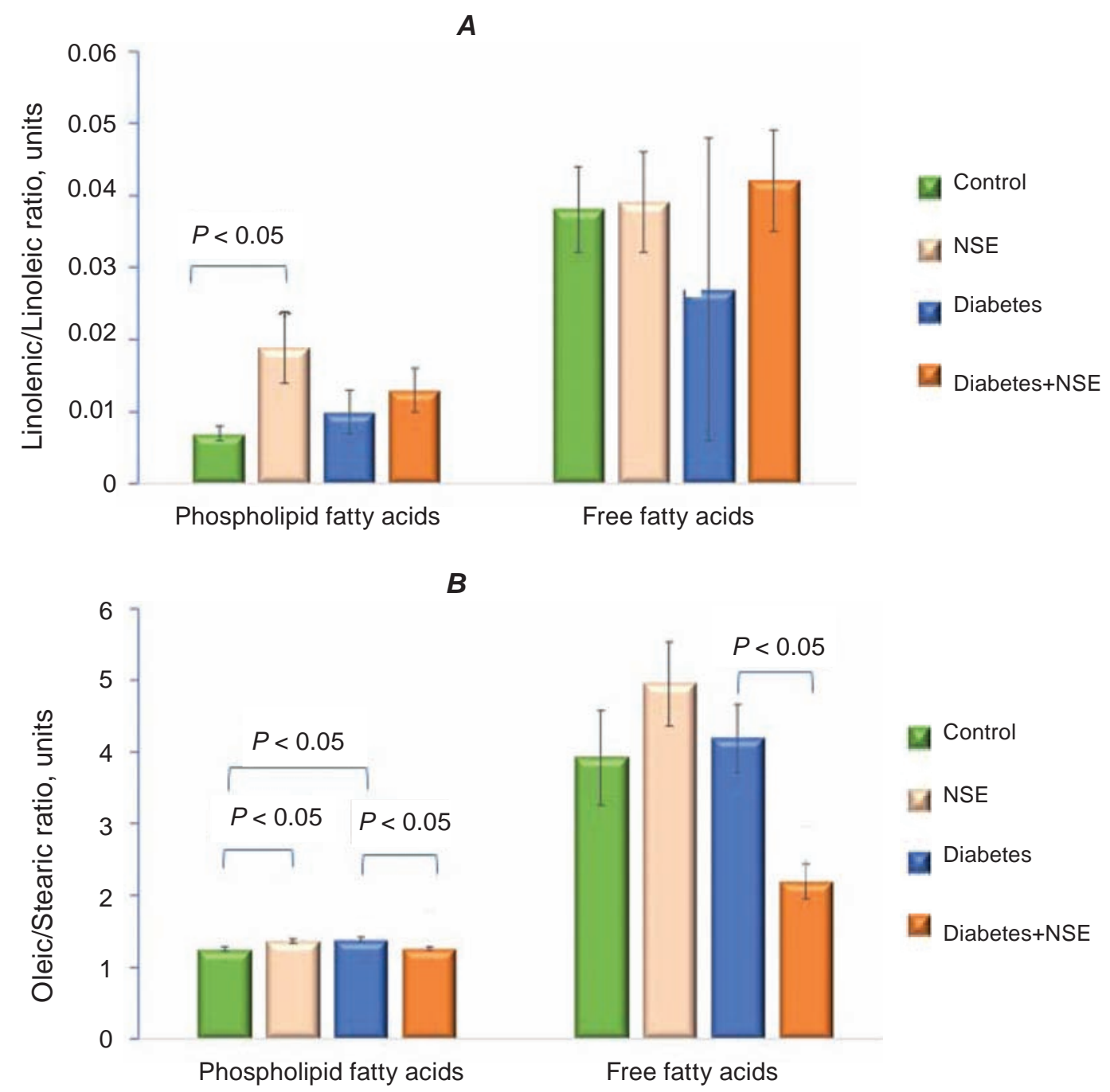

Fig. 6. (A) The linolenic/linoleic ratio and (B) oleic/stearic ratio in testes of rats with streptozotocin-induced diabetes and after $N$-stearoylethanolamine treatment (NSE). For control group and NSE group $n=7$. For each diabetic group $n=10$. Values represented as mean \pm SEM

The study of lipid composition in rat testes showed a significant increase in the content of total lipids in testes of diabetic rats with and without NSE treatment. Meanwhile, the PL composition was significantly impaired in rat testes during diabetes development. The NSE treatment of diabetic rats promoted the restoration of the particular PL level.

It was reported that the weight of testes, sperm content and motility, and testosterone level were significantly reduced in diabetic rats, and in addition, an increase in the formation of altered forms of sperm was detected [24, 25]. These disturbances played a crucial role in the development of male infertility during diabetes.

It was confirmed that in addition to a structural role, PL take part in membrane functioning, creating the surrounding area for membrane transporters, membrane-bound enzymes, participating in signal transduction. Therefore, the optimal balance of PL composition is important for the functioning of the cell membrane apparatus. Most pathological processes, such as type I diabetes, are accompanied by alterations in membrane function, followed by impaired protein and lipid composition of membranes, including PL content. Prior studies described that the morpho-functional changes in sperm during male infertility correlated with the disturbances in membrane PL composition. In particular, secretory infertility in males was associated with a reduction of the inorganic phosphorus content of sperm PL (including phosphatidylethanolamine, phosphatidylinositol, lysophosphatidylcholine), which corre- 
lated with a decrease in sperm content and indicated a disturbance in PL metabolism. Relative infertility showed a decrease in sphingomyelin and lysophosphatidylcholine, which was associated with impaired sphingomyelin metabolism and a decrease in A2 phospholipase activity [26].

It is worth noting that most of the studies of male infertility were conducted using sperm, while the main stages of spermatogenesis occur in the testes. Obviously, biochemical disorders that occur in male gonadal cells during pathology developed in the testes in early stages of spermatogenesis.

Therefore, to perform our study we used testes of diabetic rats. We have shown that under diabetic conditions there was a decrease in the level of individual PL in the testes. The major changes were found in phosphatidylcholine, phosphatidylethanolamine and phosphatidylserine content. Considering the possible mechanisms of such shifts, it was assumed that the synthesis of basic PL, in particular phosphatidylethanolamine and phosphatidylcholine, via the Kennedy pathway was inhibited, the intensity of bases exchange was decreased and the activity of phosphatidylserine decarboxylase was reduced $[27,28]$. It is known that phosphatidylserine can also be formed through acylation of 1-acylsn-glycero-3-phosphoserine [29]. Thus, we suggest that the decrease in phosphatidylserine content may be an indication of the inhibition of its synthesis via the listed mechanism. Identified changes in PL synthesis and alteration in their composition in testes along with other metabolic disorders during streptozotocin-induced diabetes may be a prerequisite for the development of male infertility.

Our previous studies showed a membranotropic effect of NSE in many experimental models associated with impaired membrane structure and function, such as ischemic-reperfusion injury, and acute toxic lesions of morphine and ethanol [30, 31].

The NSE treatment of diabetic rats restored the PL composition in testes by normalizing the level of individual PL within 10 days of administration. The observed effect of NSE confirmed its modulation of PL metabolism, restoring membrane structure and function in testes. These results are in agreement with earlier findings with another NAE representative -oleylethanolamine where in vitro capacitated spermatozoa from patients with idiopathic infertility were studied [32]. Incubation of oleylethanolamine with sperm improved its kinematic parameters and modulated hyperactivation, both in the presence and in the absence of oxidative stress, conferring protec- tion against oxidative damage. The observed effect was followed by reduction of sperm membrane lipid peroxidation and restoration of the lipid bilayer structure.

Analysis of FA composition in testes of diabetic rats showed an increase in the content of saturated FA and a decrease in the content of unsaturated FA in the pool of free and PL FAs. The following changes in the content of FAs led to an increase in the saturation index (the ratio of saturated/unsaturated FA).

The saturation index reflects the functional properties of membranes and serves as a diagnostic indicator of many pathological processes. The earlier studies described that the reduction of docosahexaenic acid in the ejaculate closely correlated with the development of various types of male infertility, such as excretory-toxic, secretory and combined [33].

It is widely known that animals have a complex system of FA biosynthesis. The main metabolic remodeling of FA in membrane lipids is realized by desaturases and FA elongases. Thus, $\Delta 9$-desaturase catalyzes the synthesis of monoenic FAs, and the product of this reaction is oleic acid. $\Delta 6$ - and $\Delta 5$ desaturases catalyze the formation of polyunsaturated FAs. To evaluate the activity of desaturases, the value of the individual FA ratio is used. Therefore, the evaluation of $\Delta 5$-desaturase activity is the ratio of arachidonic acid to dihomo gamma linolenic (eicosatrienoic) acid, $\Delta 6$-desaturase - the ratio of linolenic acid to linoleic acid, and for $\Delta 9$-desaturase the ratio of oleic acid to stearic acid [34].

The results of FA ratio estimation showed that diabetes caused an increase in the ratio of oleic to stearic acid. This finding suggested changes in $\Delta 9$ desaturase activity. The detected increase in the activity of this enzyme could be a consequence of its inverse regulation during a reduced level of monoenic FAs in the pool of free FA and PL.

Thus, an increase in the saturation index of FA and a decrease in the content of basic PL, including the "fluidity" PL - phosphatidylcholine [35], proved that the sealing of cell membranes in rat testes was a causative factor in the impairment of its functional activity.

Earlier studies indicated a close correlation between disorders in lipid composition of gonadal cells and the development of male infertility [26]. It is important to emphasize that the process of sperm maturation was associated with the changes in li- 
pid and PL composition of cell membranes. Thus, the lipid composition of epididymal and ejaculated sperm is different. In particular, during maturation of bull sperm while passing through the epididymal tract, the levels of phosphatidylcholine, phosphatidylethanolamine, cardiolipin, phosphatidylserine and sphingomyelin were significantly reduced. Similar changes were found during maturation of rat gametes where the level of PL was decreased almost three times [36].

The previous experiments described significant changes in the content of PL in male germ cells in various forms of male infertility. Namely, the analysis of PL content in sperm and seminal fluid of infertile men showed a decrease in the level of both total and individual PL [26]. It is important to note that sperm synthesis is located in male reproductive glands, while sperm differentiation - in the epididymus. Therefore, the changes in the lipid composition of spermatozoids may occur during the early stages of their formation and maturation.

NAE is a group of minor lipids whose main function is to protect and repair cell membranes during different pathological factors. The administration of NSE to rats with experimental diabetes triggered normalization of total and individual saturated and unsaturated FA of both free FA and PL FA in testes. Particular attention was paid to the increased content of docosahexaenoic acid in free FA composition of diabetic rats treated with NSE. In addition, administration of NSE to rats with diabetes resulted in a significant decrease of the estimated activity of $\Delta 9$-desaturase. Considering the crucial effect of the disturbances in FA composition on the male reproductive system, it is assumed that the corrective effect of NSE on testes lipid composition induced the restoration of its functional activity.

\section{Conclusion}

The results of this study, using NSE at a dose of $50 \mathrm{mg} / \mathrm{kg}$ of body weight for 10 days in the initial stages of streptozotocin-induced diabetes in rats, indicated the restoration of PL composition, normalization of free FA content and di-/polyunsaturated percentage of FA in PL composition of rat testes, correlating with a slight increase in the plasma testosterone level.

Therefore, the obtained results suggest the feasibility of NSE treatment during the early stages of insulin-dependent diabetes, and as a result its potential effect on prevention of male infertility.
Considering the absence of any human data on the effect of NSE, the results of the current study may provide a background for further clinical research.

Conflict of interest. Authors have completed the Unified Conflicts of Interest form at http://ukrbiochemjournal.org/wp-content/uploads/2018/12/coi_ disclosure.pdf and declare no conflict of interest.

Acknowledgements. We thank Cedar-Sinai Medical Center's International Research and Innovation in Medicine Program, and the Association for Regional Cooperation in the Fields of Health, Science and Technology (RECOOP HST Association) for their support.

Financial support. The study was supported by the Ministry of Education and Science of Ukraine.

\section{ВПЛИв \\ N-СТЕАРОІЛЕТАНОЛАМІНУ НА ВМІСТ ЛІПІДІВ У СІМ'ЯНИКАХ ТА РІВЕНЬ ТЕСТОСТЕРОНУ У ЩУ РIВ НА РАННIX СТАДІЯХ СТРЕПТОЗОТОЦИН- ІНДУКОВАНОГО ДІАБЕТУ}

\author{
О. В. Онопченко ${ }^{凶}$, Т. М. Горідько, \\ Г. В. Косякова, А. Г. Бердишев, \\ В. М. Клімашевський, Н. М. Гула \\ Інститут біохімії ім. О. В. Палладіна \\ НАН України, Київ; \\ 凶e-mail: onop.89.av@gmail.com
}

Порушення обміну речовин за діабету пов'язано 3 мультіорганними ускладненнями, включаючи дисфункцію репродуктивної системи, де ключову роль відіграє ліпідний дисбаланс сім'яників. 3 огляду на те, що $\mathrm{N}$-стеароїлетаноламін (NSE) проявляє модулюючий ефект на ліпідний склад тканин за різних патологій, метою нашого дослідження було дослідити вплив NSE на ліпідний склад сім'яників та рівень тестостерону у плазмі крові діабетичних щурів. Діабет індукували у Sprague-Dawley щурів однією ін'єкцією стрептозотоцину $(50$ мг/кг). Відбирали тварин за рівнем глюкози 8-12 ммоль/л. NSE вводили щурам (50 мг/кг) протягом 10 днів через 1,5 місяці після введення стрептозотоцину. Сім'яники щурів використовували для проведення ліпідного аналізу, а саме визначення рівня фосфоліпідів 
та метилових ефірів жирних кислот. Також, визначали вміст тестостерону у плазмі крові. Введення NSE діабетичним щурам сприяло нормалізації загального та індивідуального вмісту фосфоліпідів, а також рівня жирних кислот як вільних, так і у складі фосфоліпідів у сім'яниках. Крім того, вміст тестостерону у плазмі крові показав тенденцію до його підвищення під дією NSE. Згідно отриманих результатів ранні стадії розвитку інсулінозалежного діабету спричиняють значні зміни у сім'яниках щурів, які можуть призводити до зниження їх функціональної активності. Введення NSE діабетичним щурам нормалізує вміст ліпідів у сім'яниках щурів, сприяє підвищенню рівня тестостерону та відновлює структурно-функціональний стан сім'яників на ранніх стадіях стрептозотоцин-індукованого діабету у щурів.

К л ю ч о в і с ло в а: стрептозотоцин-індукований діабет, сім'яники, N-стеароїлетаноламін (NSE), фосфоліпіди, жирні кислоти, тестостерон.

\section{References}

1. Steer SA, Scarim AL, Chambers KT, Corbett JA. Interleukin-1 stimulates $\beta$-cell necrosis and release of the immunological adjuvant HMGB1. PLoS Med. 2006; 3(2): e17.

2. Tavares RS, Escada-Rebelo S, Silva AF, Sousa MI, Ramalho-Santos J, Amaral S. Antidiabetic therapies and male reproductive function: where do we stand? Reproduction. 2018; 155(1): R13-R37.

3. Zimmerman JJ. Oxyradical pathophysiology. Adv Pediatr. 1995; 42: 243-302.

4. Catalá A, Díaz M. Editorial: Impact of lipid peroxidation on the physiology and pathophysiology of cell membranes. Front Physiol. 2016; 7: 423.

5. Casares D, Escribá PV, Rosselló CA. Membrane lipid composition: Effect on membrane and organelle structure, function and compartmentalization and therapeutic avenues. Int J Mol Sci. 2019; 20(9): 2167.

6. Gennis RB. Biomembranes: Molecular Structure and Function. Springer-Verlag, 1989. 533 p.

7. Stubbs CD, Smith AD. The modification of mammalian membrane polyunsaturated fatty acid composition in relation to membrane fluidity and function. Biochem Biophys Acta. 1984; 779(1): 89-137.
8. Duplus E, Glorian M, Forest C. Fatty acid regulation of gene transcription. $\mathrm{J}$ Biol Chem. 2000; 275(40): 30749-30752.

9. Jump DB, Clarke SD. Regulation of gene expression by dietary fat. Annu Rev Nutr. 1999; 19(1): 63-90.

10. Zhukov OD, Berdyshev AH, Kosiakova HV, Klimashevs'kyı̌ VM, Horid'ko TM, Mehed OF, Hula NM. N-stearoylethanolamine effect on the level of 11-hydroxycorticosteroids, cytokines IL-1, IL-6 and TNFalpha in rats with nonspecific inflammation caused by thermal burn of skin. Ukr Biochem J. 2014; 86(3): 88-97. (In Ukrainian).

11. Onopchenko OV, Kosiakova $\mathrm{GV}, \mathrm{Oz} \mathrm{M}$, KlimashevskyVM, Gula NM.N-stearoylethanolamine restores pancreas lipid composition in obesity-induced insulin resistant rats. Lipids. 2015; 50(1): 13-21.

12. Saturnino C, Popolo A, Ramunno A, Adesso S, Pecoraro M, Plutino MR, Rizzato S, Albinati A, Marzocco S, Sala M, Iacopetta D, Sinicropi MS. Anti-inflammatory, antioxidant and crystallographic studies of N-palmitoylethanol amine (PEA) derivatives. Molecules. 2017; 22(4): 616.

13. Carbonare DM, Giudice DE, Stecca A, Colavito D, Fabris M, D'Arrigo A, Bernardini D, Dam M, Leon A. A saturated N-acylethanolamine other than N-palmitoyl ethanolamine with antiinflammatory properties: a neglected story. $J$ Neuroendocrinol. 2008; 20(Suppl 1): 26-34.

14. A.S. SU 1690736 A1. Method of cryopreservation of sperm. Gulaya NM, Volkov GV, Vysotsky MV, Melnichuk DA, Ivanenko FV Publ. 15.11.91. Bul. N 42.

15. Kolb VG, Kalashnikova VS. Clinical Biochemistry. M.: Belarus, 1976. 311 p. (In Russian).

16. Bligh EG, Dyer WI. A rapid method of total lipid extraction and purification. Can J Biochem Physiol. 1959; 37(8): 911-917.

17. Vaskovsky VE. Kostetsky EV, Vasendin IM. A universal reagent for phospholipid analysis. $J$ Chromatogr. 1975; 114(1): 129-141.

18. Vaskovsky VE, Terekhova TA. HPTLC of phospholipid mixtures containing phosphatidylglycerol. J High Resol Chromatogr. 1979; 2(11): 671-672.

19. Svetashev VI, Vaskovsky VE. A simplified technique for thin-layer microchromatography of lipids. J Chromatogr. 1972; 67(2): 376-378. 
20. Carreau ID, Dubacq IP. Adaptation of a macroscale method to the micro-scale for fatty acid methyl transeterification of a biological lipid extraction. J Chromatogr. 1978; 151(3): 384-390.

21. Schuel H, Burkman LJ, Lippes J, Crickard K, Forester E, Piomelli D, Giuffrida A. $\mathrm{N}$-acylethanolamines in human reproductive fluids. Chem Phys Lipids. 2002; 121(1-2): 211227.

22. Amoako AA, Marczylo TH, Elson J, Taylor AH, Willets JM, Konje JC. Relationship between seminal plasma levels of anandamide congeners palmitoylethanolamide and oleoylethanolamide and semen quality. Fertil Steril. 2014; 102(5): 1260-1267.

23. Bloch KO, Poltorak VV. Genetic control of sensitivity to diabetogenic effects. Usp Sovrem Biol. 1989; 108: 386-400. (In Russian).

24. Kühn-Velten N, Schermer R, Staib W. Effect of streptozotocin-induced hyperglycaemia on androgen-binding protein in rat testis and epididymis. Diabetologia. 1984; 26(4): 300-303.

25. Scarano WR, Messias AG, Oliva SU, Klinefelter GR, Kempinas WG. Sexual behaviour, sperm quantity and quality after shortterm streptozotocin-induced hyperglycaemia in rats. Int J Androl. 2006; 29(4): 482-488.

26. Gulaya NM, Margitich VM, Govseeva NM, Klimashevsky VM, Gorpynchenko II, Boyko MI. Phospholipid composition of human sperm and seminal plasma in relation to sperm fertility. Arch Androl. 2001; 46(3): 169-175.

27. Kennedy EP, Borkenhagen LF, Smith SW. Possible metabolic functions of deoxycytidine diphosphate choline and deoxycytidine diphosphate ethanolamine. J Biol Chem. 1959; 234(8): 1998-2000.

28. Tijburg LBM, Geelen MJH, van Golde van LMG. Regulation of the biosynthesis of triacylglycerol, phosphatidylcholine and phosphatidylethanolamine in the liver. Biochem Biophys Acta. 1989; 1004(1): 1-19.
29. Holub BJ. The biosynthesis of phosphatidylserine by acylation of 1-acyl-sn-glicero-3phosphoserine in rat liver. Biochim Biophys Acta. 1980; 618(2): 255-262.

30. Artamonov MV, Zhukov OD, Goryd'ko TM, Klimaschevsky VM, Martsenyuk OP, GulayaNM. Influence of N-stearoylethanolamine (NSE) on the lipid components of the rat liver and heart microsome fractions under X-ray ionization. Ukr Biokhim Zhurn. 2003; 75(4): 8190. (In Ukrainian).

31. Gula NM, Margitych VM, Artamonov MV, Zhukov OD, Goridko TM, Klimashevsky VM. Neuroprotective effect of $\mathrm{N}$-acylethanolamines under chronic morphine dependence. I. Rat brain phospholipids as a rational target of their action Ukr Biokhim Zhurn. 2004; 76(5): 123-131. (In Ukrainian).

32. Ambrosini A, Zolese G, Ambrosi S, Ragni L, Tiano L, Littarru G, Bertoli E, Mantero F, Boscaro M, Balercia G. Oleoylethanolamide protects human sperm cells from oxidation stress: Studies on cases of idiopathic infertility. Biol Reprod. 2006, 74(4): 659-665.

33. Margitich VM. Changes in the composition of fatty acids in the ejaculate of infertile men with normal sperm. Journal NAMSU. 2001; 7(2): 359363.

34. Dorrance AM, Graham D, Dominiczak A, Fraser R. Inhibition of nitric oxide synthesis increases erythrocyte membrane fluidity and unsaturated fatty acid content. Am J Hypertens. 2000; 13(11): 1194-1202.

35. Shinitzky M. Barenholz Y. Dynamics of the hydrocarbon layer in liposomes of lecithin and sphingomyelin containing dicetylphosphate. $J$ Biol Chem. 1974; 249(8): 2652-2657.

36. Parks JE, Hammerstedt RH. Developmental changes occuring in the lipids of rat epididimal spermatozoa plasma membrane. Biol Reprod. 1985; 32(3): 653-668. 